\section{Ossifying Fibroma of the Jaws: A Clinicopathological Case Series Study}

Márcia de Andrade, Yara Teresinha Corrêa Silva-Sousa, Maria Fernanda Teiga Marques, Maria Luiza dos Anjos Pontual, Flávia Maria de Moraes Ramos-Perez, Danyel Elias da Cruz Perez

\author{
Department of Clinical and \\ Preventive Dentistry, School of \\ Dentistry, UFPE - Federal University \\ of Pernambuco, Recife, PE, Brazil \\ Correspondence: Prof. Dr. Danyel \\ Elias da Cruz Perez, Avenida \\ Prof. Moraes Rego, 1235, Cidade \\ Universitária, 50670-901 Recife, \\ PE, Brazil. Tel: +55-81-2126-7510. \\ e-mail: danyel.perez@ufpe.br
}

The aim of this study was to assess the clinical, radiographic and microscopic features of a case series of ossifying fibroma (OF) of the jaws. For the study, all cases with OF diagnosis from the files of the Oral Pathology Laboratory, University of Ribeirão Preto, Ribeirão Preto, SP, Brazil, were reviewed. Clinical data were obtained from the patient files and the radiographic features were evaluated in each case. All cases were reviewed microscopically to confirm the diagnosis. Eight cases were identified, 5 in females and 3 in males. The mean age of the patients was 33.7 years and most lesions ( 7 cases) occurred in the mandible. Radiographically, all lesions appeared as unilocular images and most of them ( 5 cases) were of mixed type. The mean size of the tumor was $3.1 \mathrm{~cm}$ and 3 cases caused displacement of the involved teeth. Microscopically, all cases showed several bone-like mineralized areas, immersed in the cellular connective tissue. From the 8 cases, 5 underwent surgical excision and 1 patient refused treatment. In the remaining 2 cases, this information was not available. In conclusion, OF occurs more commonly in women in the fourth decade of life, frequently as a mixed radiographic image in the mandible. Coherent differential diagnoses are important to guide the most adequate clinical approach. A correlation between clinical, imaginological and histopathological features is the key to establish the correct diagnosis.
Key Words: case series, differential diagnosis, ossifying fibroma, radiographic features.

\section{Introduction}

Fibro-osseous lesions is a term used for a group of diseases of the jaws in which the normal bone tissue is replaced by fibroblasts and fibrous tissue, with formation of variable amounts of mineralized material (1). This term does not represent a specific diagnosis. Fibrous dysplasia, osseous dysplasia and ossifying fibroma compose the group of fibro-osseous lesions. Despite the similarities in clinical, radiographic and histopathological features of these lesions, these lesions are of distinct nature (1). Osseous dysplasia and fibrous dysplasia are reactive lesions while ossifying fibroma is a true neoplasm. In consequence, the fibroosseous lesions present different biological behavior $(1,2)$. Thus, a correct final diagnosis is essential.

The ossifying fibroma (OF) is a benign neoplasm that affects the jaws. This lesion occurs more often in females in the third and fourth decades of life. Usually, OF appears as a single, painless and slow-growing lesion, mostly found in the posterior region of the mandible, specifically in the premolars and molars area $(2,3)$.

Radiographically, OFs present as a unilocular and wellcircumscribed image, initially radiolucent, and as they progress, appear as mixed lesions, with radiolucent and radiopaque areas. The older lesions are radiopaque and surrounded by a radiolucent halo $(2,4)$. Microscopically, this neoplasm is composed of a proliferation of benign spindle cells, forming a cellular connective tissue and a mineralized tissue similar to bone or cementum (5).

The treatment consists in completely removing the lesion with curettage, surgical excision or en-block resection, depending on the size and location of the lesion $(3,4)$. In lesions with a fibrous capsule around, the surgical excision may be performed more easily (6). Recurrences are rarely observed $(2,4)$.

$\mathrm{OF}$ is an uncommon lesion and few series of cases have been published $(2,4,7,8)$. Thus, the aim of this study was to assess the clinical, radiographic and microscopic features in an OF case series.

\section{Material and Methods}

Between 2000 and 2010, all cases of ossifying fibroma diagnosed at the Oral Pathology Laboratory, University of Ribeirão Preto, SP, Brazil, were analyzed. Clinical data such as age, gender and time of complaints of the patients, location and size of the tumor were obtained from the patient files in the Laboratory. The radiographic features were evaluated in each case. Cases with incomplete data were excluded.

After biopsy or surgical treatment, the specimens were fixed in 10\% formaldehyde solution for $24 \mathrm{~h}$. For conventional histological processing, the tissues were dehydrated in increasing concentrations of ethanol, immersed in xylene and then embedded in paraffin. 
Histological 5- $\mu m$-thick sections were obtained from paraffin-embedded tissue blocks and stained with hematoxylin-eosin. All cases were microscopically reviewed to confirm the diagnosis. The diagnosis was established based on the clinical, radiographic and histopathological features.

\section{Results}

Eight cases of ossifying fibroma were diagnosed. There were 5 women and 3 men. The mean age of the patients was 33.7 years (ranging from 13.0 to 49.0 years). Most lesions (7 cases, $87.5 \%$ ) occurred in the mandible; 4 of them occurred in the anterior region and 3 in the posterior region. In the diagnosis, the mean time of complaints was 37 months (ranging from 2.0 to 60.0 months). Four patients (50\%) reported painless swelling in the affected region (Fig. 1). One case $(12.5 \%)$ reported mild pain without swelling and another reported tooth displacement. The information on complaints was not available in 2 cases. The clinical and epidemiological data are summarized in Table 1.

Radiographically, most cases (5 cases, 62.5\%) showed

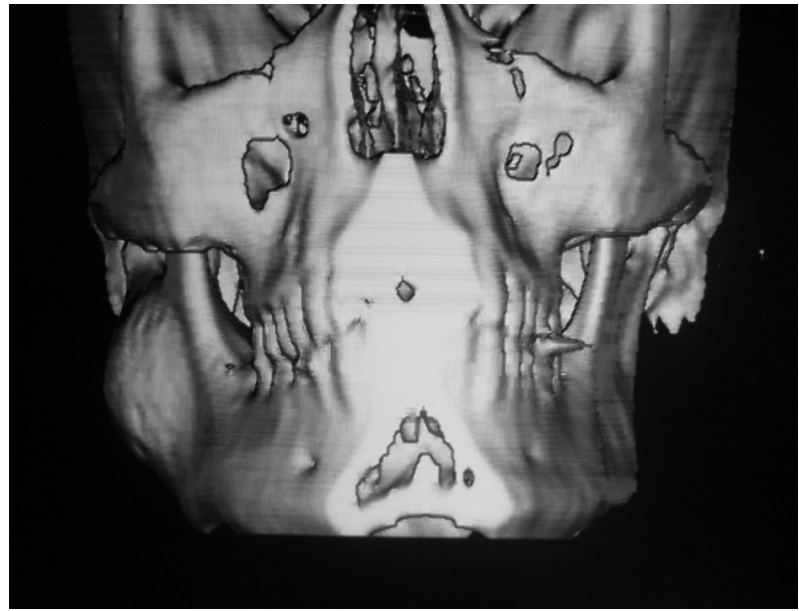

Figure 1. 3D reconstruction from multiple images reveals swelling in the affected area (case 6).

Table 1. Clinical and epidemiological data of ossifying fibroma of the jaws

\begin{tabular}{lccccc}
\hline Case & $\begin{array}{c}\text { Age } \\
\text { (years) }\end{array}$ & Gender & $\begin{array}{c}\text { Duration } \\
\text { (months) }\end{array}$ & $\begin{array}{c}\text { Patient } \\
\text { complaint }\end{array}$ & Site \\
\hline 1 & 40 & Female & 5.0 & Mild pain & AMD \\
2 & 13 & Male & 2.0 & Tooth displacement & AMX \\
3 & 49 & Male & 20.0 & NA & PMD \\
4 & NA & Female & 2.0 & NA & AMD \\
5 & 46 & Female & 60.0 & Painless swelling & PMD \\
6 & 17 & Male & NA & Painless swelling & PMD \\
7 & 51 & Female & 60.0 & Painless swelling & AMD \\
8 & 20 & Female & 8.0 & Painless swelling & AMD \\
\hline
\end{tabular}

*NA: Not available. AMX: Anterior maxilla. AMD: Anterior mandible. PM: Posterior mandible. mixed images, and all lesions were unilocular and well circumscribed (Figs. 2 and 3 ). The mean size of the lesions was $3.0 \mathrm{~cm}$ (ranging from 1.0 to $6.0 \mathrm{~cm}$ ). Three cases (37.5\%) caused dental displacement (cases 2, 5 and 8). One case (case 1) was located in the periapical region of the right mandibular canine that was endodontically treated. In this case, the lesion extended into the apical region of the adjacent lateral incisor. The patient complained of slight pain, exacerbated during palpation. Table 2 shows the main radiographic features.

Microscopically, all cases were composed of connective tissue of mixed and variable cell types, with a mineralized component that consisted of trabecular or woven bone. Osteoblastic rimming was commonly observed (Fig. 4).

Most cases ( 5 cases) were treated by surgical excision of the lesion. However, one patient refused treatment and in 2 cases this information was not available.

\section{Discussion}

In fibro-osseous lesions, the presence of a mineralized

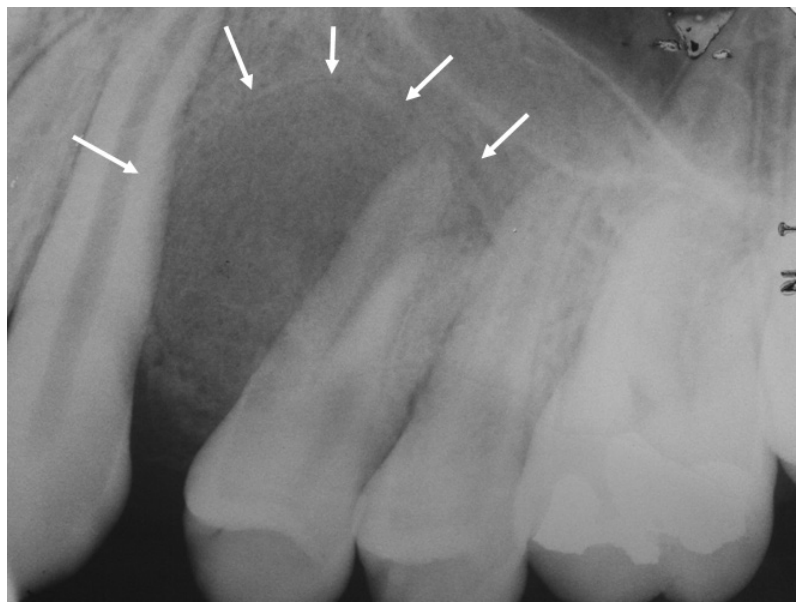

Figure 2. Well-delimited mixed radiographic image causing displacement of the involved teeth (case 2).

Table 2. Radiographic features of all ossifying fibroma cases

\begin{tabular}{lccc}
\hline Case & $\begin{array}{c}\text { Radiographic } \\
\text { feature }\end{array}$ & $\begin{array}{c}\text { Radiographic } \\
\text { density }\end{array}$ & Size $(\mathrm{cm})$ \\
\hline 1 & Unilocular & Radiolucent & 1.0 \\
2 & Unilocular & Mixed & 2.0 \\
3 & Unilocular & $\mathrm{NA}^{*}$ & $\mathrm{NA}$ \\
4 & Unilocular & Mixed & 2.0 \\
5 & Unilocular & Radiopaque & 1.0 \\
6 & Unilocular & Mixed & 6.0 \\
7 & Unilocular & Mixed & 5.0 \\
8 & Unilocular & Mixed & 4.0 \\
\hline
\end{tabular}

*NA: Not available 
tissue with spheroid-laminated appearance is described as similar to cementum. However, cementum is a bone-like mineralized tissue deposited on the root surface of a tooth. Therefore, in addition to the mineralized tissue structure, the anatomic site is essential to characterize the cementum (8). Currently, the World Health Organization recommends the use of ossifying fibroma and osseous dysplasia, replacing the cement-ossifying fibroma and cement-osseous dysplasia, which exclude the term "cementum" (9).

The $\mathrm{OF}$ is a relatively rare benign tumor that affects the mandible and maxilla. Although OF appears as a single slow growth lesion $(2,4)$, a few cases of multiple tumors have been reported (10). These lesions are more frequent in women and occur more commonly between the third and fourth decades of life $(2,5,11)$, similar to the current case
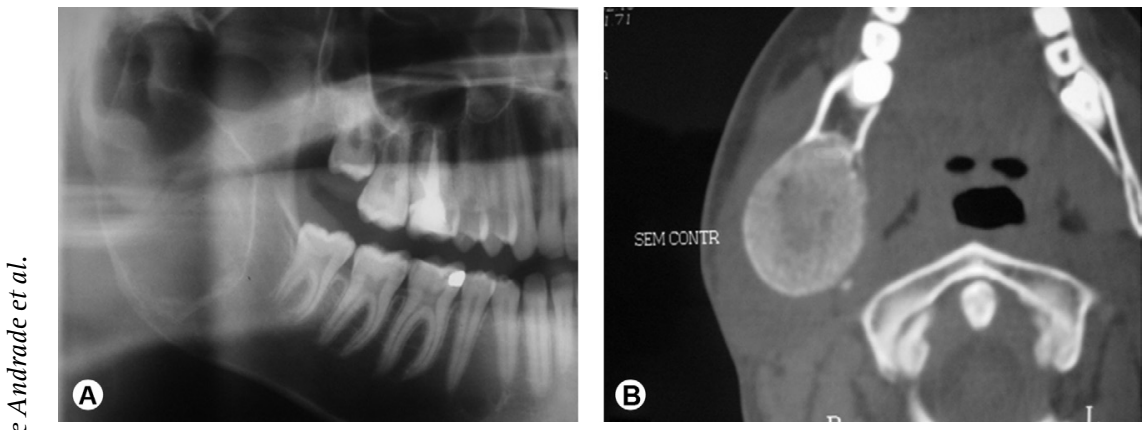

$\dot{\Sigma}$

Figure 3. Case 6. A: Well-delimited large radiolucent image located in the right mandibular ramus. B: CT scan showing well-circumscribed mixed image.

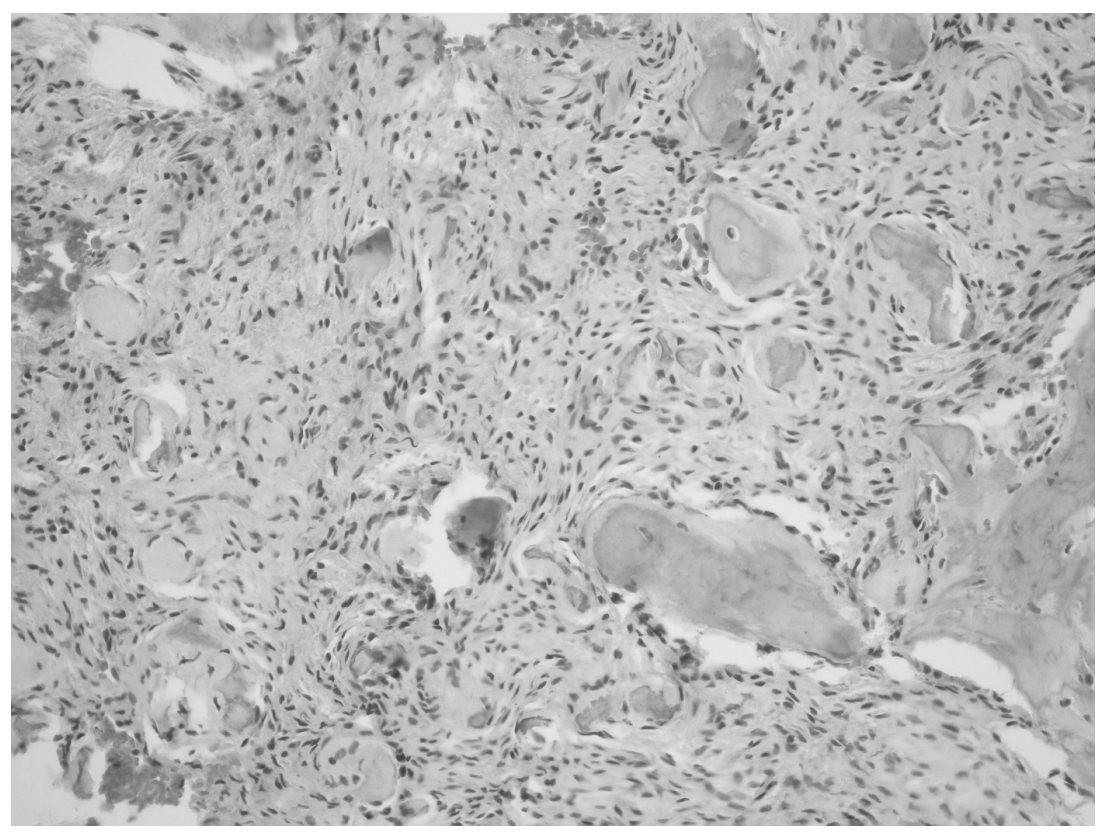

Figure 4. Mineralized material composed by woven bone interspersed by cellularized connective tissue (HE, original magnification $100 \times$ ). series. However, 3 cases occurred in young patients. In the present study, all but one case occurred in the mandible, as observed by several authors $(2,7)$. Nevertheless, in contrast to most studies in the literature $(2,4,7)$, in this series, almost half of the mandibular cases affected the posterior region. Chang et al. (2) found that $61 \%$ of the cases affected the posterior region of the mandible. This divergence may be due to differences in the number of cases in previously published series or eventual geographic aspects when comparing series published around the world $(2,4,6)$.

Swelling in the affected region is the most common clinical sign observed in patients with OF. They are usually painless and eventually identified in routine radiographic examination (3). From the 8 cases presented in this study, most of them exhibited swelling on the tumor site and only one reported mild pain. OF may cause tooth displacement and root resorption in adjacent teeth (12). In the current series, 3 cases presented tooth displacement, which was the main complaint in one case. No root resorption was observed.

Radiographically, the features of OF may vary depending on the amount of mineralized tissue within the tumor. OFs usually appear as unilocular, well-delimited lesions, with variable amount of radiopaque foci inside the lesion (1). Consequently, a mixed radiographic image is commonly observed $(2,7)$. In the present series, $62.5 \%$ of the lesions showed mixed images. Computerized tomography (CT) is essential for a complete evaluation of the lesions. In panoramic radiographic examination, case 6 showed a predominantly radiolucent image. On the other hand, a CT image revealed an unequivocal mixed image located in the right mandibular ramus. Based on this additional information, several image examinations should be used for the correct assessment and diagnosis of intra-osseous lesions. However, as this series was based on data from an oral pathology laboratory, the analysis of additional image examinations could not be performed. Enlargement of the OF may increase the amount of mineralized material inside the 
tumor. Nevertheless, the use of the term maturation to characterize this phenomenon in neoplastic lesions is controversial. Neoplasms have an unlimited growth and do not mature from a biological perspective. This term should be used preferentially for dysplastic lesions like the osseous dysplasias (8).

$\mathrm{OF}$ is classified as a maxillofacial fibro-osseous lesion. Fibrous dysplasia and osseous dysplasia are other conditions considered in the group of fibro-osseous lesions $(8,11)$. Fibrous dysplasia is the main lesion in the differential diagnosis of OF (4). Radiographically, fibrous dysplasia usually appears as a diffuse, homogeneous ground-glass, radiodense region, whereas the OF shows a well-demarcated mixed radiolucent and radiopaque image $(11,13)$, as observed in all cases from this series, which were well-circumscribed and separated from the cortical bone. Osseous dysplasia may appear in three different clinicoradiographic patterns, namely florid, focal or periapical osseous dysplasia $(9,14)$. Among the osseous dysplasias, focal osseous dysplasia (FOD), in early, intermediate and late stage, is an important differential diagnosis for OF (2). Differently from OF, FOD occurs more frequently in patients during the fourth and fifth decades of life and usually presents ill-defined radiographic borders. Moreover, the lesions in FOD are smaller than in OF and affect more frequently the periapical region (6). In this series, case 1 is located in the periapical region. In the present case, although the lesion presented a small dimension, it extended into the apical region of the adjacent lateral incisor. Additionally, the patient complained of slight pain, which was exacerbated during palpation. These features strongly suggested lesion growth. In contrast, most FOD are fully asymptomatic and diagnosed in a routine radiographic examination $(13,15,16)$.

Apart from the fibro-osseus lesions, other diseases may be included in the differential diagnosis of OF. In fact, the differential diagnosis depends on the radiographic features of the lesion. In OF, it appears as a radiolucent image, odontogenic cysts, ameloblastoma, central giant cell lesions, chronic apical periodontitis and idiopathic bone cavity (2). For mixed lesions, osteoblastoma, calcifying cystic odontogenic tumor and calcifying epithelial odontogenic tumor should be considered in the differential diagnosis (2). Finally, for radiopaque $O F$, complex odontoma and idiopathic osteosclerosis are the main differential diagnoses. OF may also resemble a cementoblastoma if it occurs around the tooth root (4); however, cementoblastoma is fused to the tooth root. In large OFs, osteosarcoma may be also considered in the clinico-radiographic diagnosis, since osteosarcomas of the jaws affect patients in a similar age range (17).

Microscopically, OF consists in a cellular connective tissue that presents mineralized material, with an osteoblastic rimming commonly observed on the surface of the mineralized tissue (15), similar to observed in most cases of this current series. Recently, a study demonstrated that the presence of peritrabecular clefting in fibrous dysplasia is an important histopathological feature for distinguishing fibrous dysplasia from OF (18). Moreover, considering fibro-osseous lesions, mainly the fibrous dysplasia, the presence of mutations at the Arg201 codon of the alpha subunit of the stimulatory $\mathrm{G}$ protein is observed only in fibrous dysplasia (19).

Juvenile trabecular fibroma (JTOF) and juvenile psammomatoid ossifying fibroma (JPOF) are other histological OF types. In contrast with conventional OF, JTOF and JPOF occur most commonly in the maxilla and bony walls of paranasal sinuses, respectively. Both present predilection for patients up to the second decade of life. JTOFs usually show an aggressive and rapid growth $(13,15)$, different from the ones in the current study.

The treatment of ossifying fibroma is a complete removal by curettage or excision $(2,4)$. In this study, five of the lesions were submitted to surgical excision. One patient refused treatment and in two cases information on the treatment was not available. After treatment, recurrences are rare.

In conclusion, OF occurs more commonly in women in the fourth decade of life, frequently as a mixed radiographic image in the mandible. Coherent differential diagnoses are important to guide the most adequate clinical approach. A correlation between clinical, imaginological and histopathological features is the key to establish the correct diagnosis.

\section{Resumo}

0 objetivo deste estudo foi analisar as características clínico-radiográficas e microscópicas de uma série de casos de fibroma ossificante (FO). Para o estudo, todos os casos com diagnóstico de FO do arquivo do Laboratório de Patologia Bucal da Universidade de Ribeirão Preto, Ribeirão Preto, São Paulo, Brasil, foram estudados. Os dados clínicos foram coletados das fichas de encaminhamento das lesões ao Laboratório. As características radiográficas foram avaliadas em cada caso. Todos os casos foram revisados microscopicamente para confirmação do diagnóstico. Oito casos foram identificados, 5 em mulheres e 3 em homens. A idade média dos pacientes foi de 33,7 anos e a maioria das lesões (7 casos) ocorreu na mandibula. Radiograficamente todas as lesões se apresentavam como imagens uniloculares e a maioria ( 5 casos) se mostravam como imagem mista. 0 tamanho médio do tumor foi de $3,1 \mathrm{~cm}$ e 3 casos causavam deslocamento dos dentes envolvidos. Microscopicamente, todos os casos apresentavam várias áreas mineralizadas semelhantes a osso, imersas em um tecido conjuntivo celularizado. Dos 8 casos, 5 foram submetidos a excisão cirúrgica da lesão e 1 paciente recusou tratamento. Nos outros 2 casos, essa informação não estava disponível. Conclui-se que o FOs ocorrem mais comumente na mandibula de pacientes do gênero feminino durante a quarta década de vida e se apresentam frequentemente como uma imagem radiográfica mista. Diagnósticos diferenciais coerentes são importantes para guiar a conduta clínica mais adequada. A correlação entre as características clínicas, imaginológicas e histopatológicas é a 
chave para estabelecer o diagnóstico correto.

\section{References}

1. Gondivkar SM, Gadbail AR, Chole R, Parikh RV, Balsaraf S. Ossifying fibroma of the jaws: report of two cases and literature review. Oral Oncol 2011;47:804-809.

2. Chang CC, Hung HY, Chang JY, Yu CH, Wang YP, Liu BY, Chiang CP. Central ossifying fibroma: a clinicopathologic study of 28 cases. J Formos Med Assoc 2008;107:288-294.

3. Vegas Bustamante E, Gargallo Albiol J, Berini Aytés L, Gay Escoda C. Benign fibro-osseous lesions of the maxillas: analysis of 11 cases. Med Oral Patol Oral Cir Bucal 2008;13:E653-E656.

4. Triantafillidou K, Venetis G, Karakinaris G, lordanidis F. Ossifying fibroma of the jaws: a clinical study of 14 cases and review of the literature. Oral Surg Oral Med Oral Pathol Oral Radiol 2012;114:193199.

5. de Moraes Ramos-Perez FM, Soares UN, Silva-Sousa YT, da Cruz Perez DE. Ossifying fibroma misdiagnosed as chronic apical periodontitis. J Endod 2010;36:546-548.

6. Su L, Weathers DR, Waldron CA. Distinguishing features of focal cementoosseous dysplasia and cemento-ossifying fibromas II. A Clinical and radiologic spectrum of 316 cases. Oral Surg Oral Med Oral Pathol Oral Radiol Endod 1997;84:540-549.

7. de Noronha Santos Netto J, Machado Cerri J, Miranda AM, Pires FR. Benign fibro-osseous lesions: clinicopathologic features from 143 cases diagnosed in an oral diagnosis setting. Oral Surg Oral Med Oral Pathol Oral Radiol 2013;115:e56-e65.

8. Noffke CE, Raubenheimer EJ, MacDonald D. Fibro-osseous disease: harmonizing terminology with biology. Oral Surg Oral Med Oral Pathol Oral Radiol 2012;114:388-392.
9. Barnes L, Eveson JW, Reichart P, Sidransky D, eds. Pathology \& Genetics of Head and Neck Tumors. Lyon: IARC Press, 2005

10. Ribeiro $A C$, Carlos $R$, Díaz $K P$, Gouvêa $A F$, Vargas PA. Bilateral central ossifying fibroma affecting the mandible: report of an uncommon case and critical review of the literature. Oral Surg Oral Med Oral Pathol Oral Radiol Endod 2011;111:e21-e26.

11. McCarthy EF. Fibro-osseous lesions of the maxillofacial bones. Head Neck Pathol 2013;7:5-10.

12. White SC, Pharoah MJ. Oral radiology principles and interpretation. 5th ed. Mosby; 2004. p. 498-501.

13. Slootweg PJ. Lesions of the jaws. Histopathology 2009;54:401-418.

14. Gündüz $K$, Avsever $H$, Karaçayli U, Senel B, Piskin B. Florid cementoosseous dysplasia: a case report. Braz Dent J 2009;20:347-350.

15. Slootweg PJ. Osseous dysplasia. In: Barnes L, Eveson JW, Reichart $P$, Sidransky D, eds. Pathology \& Genetics Head and Neck Tumors. Lyon: IARC Press; 2005. p. 323.

16. Eversole R, Su L, El Mofty S. Benign fibro-osseous lesions of the craniofacial complex. A review. Head and Neck Pathol 2008;2:177-202.

17. Junior AT, de Abreu Alves F, Pinto CA, Carvalho AL, Kowalski LP, Lopes MA. Clinicopathological and immunohistochemical analysis of twentyfive head and neck osteosarcomas. Oral Oncol. 2003;39:521-530.

18. Prado Ribeiro AC, Carlos R, Speight PM, Hunter KD, Santos-Silva $A R$, de Almeida OP, et al.. Peritrabecular clefting in fibrous dysplasia of the jaws: an important histopathologic feature for differentiating fibrous dysplasia from central ossifying fibroma. Oral Surg Oral Med Oral Pathol Oral Radiol 2012;114:503-508.

19. Toyosawa $S$, Yuki M, Kishino M, Ogawa $Y$, Ueda $T$, Murakami $S$, et al.. Ossifying fibroma vs fibrous dysplasia of the jaw: molecular and immunological characterization. Mod Pathol 2007;20:389-396.

Received April 4, 2013 Accepted November 12, 2013 